\title{
Analisis Dampak Implementasi Dana Desa dan Alokasi Dana Desa terhadap Tata Kelola Pemerintahan, Kualitas Layanan Publik, Dan Kesejahteraan Masyarakat Desa (Studi Pada Desa di Kecamatan Batang Cenaku, Kabupaten Indragiri Hulu, Provinsi Riau)
}

\author{
Suwaji $^{1^{*}}$, Suharmiyati ${ }^{2}$ \\ ${ }^{1,2}$ Program Studi Manajemen STIE Indragiri Rengat \\ Jl. R. Soeprapto No 14. RengatTelp (0769) 21019 KodePos: 29312 \\ *Correspondence email: suwaji@ stieindragiri.ac.id, ${ }^{2}$ suharmiyati@ stieindragiri.ac.id
}

\begin{abstract}
The government policy of disbursing Village Funds and Village Fund Allocation is a breakthrough that is able to provide new enthusiasm for the implementation of rural development, where village funds obtain a clear source, direction of implementation, supervision and reporting system, it is expected to be able to spur improvement in village governance and grow impact on improving the welfare of the village or village community. The research was carried out in the village in the scope of Batang Cenaku District, Indragiri Hulu Regency, Riau Province. The research objective is to get an idea of the extent of the impact of the implementation of village funds on village governance, the quality of public services, and the welfare of village communities. This study uses primary and secondary data with a quantitative descriptive approach, from questionnaires that have been successfully distributed and collected then conducted a descriptive analysis, to test hypotheses using SPSS program tools. The results of the analysis that have been done show that the implementation of village funds has a positive impact on governance, implementation of village funds and allocation of village funds have a positive impact on the quality of public services, and implementation of village funds and allocation of village funds have a positive impact on the welfare of the community in the village, however if viewed more closely, the impact of implementing village funds and allocation of village funds on village governance is higher than the impact of implementing village funds on the quality of public services, and the impact of implementing village funds and allocation of village funds in improving the welfare of village communities.
\end{abstract}

Keywords: Village Funds, Village Fund Allocation, Governance, Service Quality, Village Community Welfare

\section{Pendahuluan}

Desa merupakan satuan pemerintahan terkecil yang memiliki peranan fundamental bagi penyelenggaraan negara, maka pemerintahan Desa diharapkan memiliki kemampuan di dalam menyelenggarakan urusan pemerintahan umum desa serta layanan kepada masyarakat yang terarah dan terfokus sesuai dengan kebutuhan desa dan memang berimbas secara langsung dengan tujuan akhir yaitu perwujudan desa yang mandiri, hal ini juga berarti bahwa kemandirian desa akan sangat erat hubungannya dengan kemampuan penataan desa dalam wujud pemerintahan desa yang efektif dan efisien, sebagaiman tujuan penataan desa yang tertuang dalam Pasal 7 ayat (3) Undang Undang Nomor 6 Tahun 2014 tentang Desa sebagai berikut: a) Mewujudkan efektivitas penyelenggaraan Pemerintahan Desa; b) Mempercepat peningkatan kesejahteraan Desa; c) Mempercepat peningkatan kualitas layanan publik; d) Meningkatkan kualitas tata kelola Pemerintahan Desa; dan e) Meningkatkan daya saing Desa. Untuk mencapai perwujudan desa yang mandiri tersebut, pemerintah telah memfasilitasi melalui Peraturan Pemerintah Nomor 60 Tahun 2014 tentang Dana Desa, dan Peraturan Menteri Dalam Negeri No. 37 tahun 2007 Tentang Pedoman Pengelolaan Keuangan Desa berupa yang dukungan dana dari pemerintah daerah yang disebut Alokasi Dana Desa (ADD), tujuan utama dari pengucuran dana tersebut adalah sebagai stimulan atau dana perangsang dengan pembiayaan program pemerintah desa yang ditunjang oleh partisipasi dan swadaya masyarakat dalam melaksanakan kegiatan pemerintahan dan pemberdayaan masyarakat. Kedua arus dana yang masuk ke desa tersebut diantara tujuan akhirnya adalah tata kelola desa yang lebih baik dengan kualitas pelayanan yang prima dan masyarakatnya yang sejahtera.

Kecamatan Batang Cenaku mrupakan salah satu kecamatan dari 14 kecamatan yang ada di Kabupaten Indragiri Hulu yang wilayahnya meliputi 20 desa dengan jumlah penduduk sebanyak 33.667 jiwa. Adapaun rata-rata Dana Desa dan Alokasi Dana Desa yang sudah diterima di setiap desa pada 20 desa di Kecamatan Batang Cenaku Selama Tahu 2016 sampai dengan 2019 sebagai berikut. 
Suwaji dan Suharmiyati, Analisis Dampak Implementasi Dana Desa dan Alokasi Dana Desa Terhadap Tata Kelola Pemerintahan, Kualitas Layanan Publik, Dan Kesejahteraan Masyarakat Desa (Studi Pada Desa di Kecamatan Batang Cenaku, Kabupaten Indragiri Hulu, Provinsi Riau)

\section{Gambar 1}

Rata-rata Jumlah Dana Desa dan Alokasi Dana Desa di setiap Desa di Kecamatan Batang Cenaku

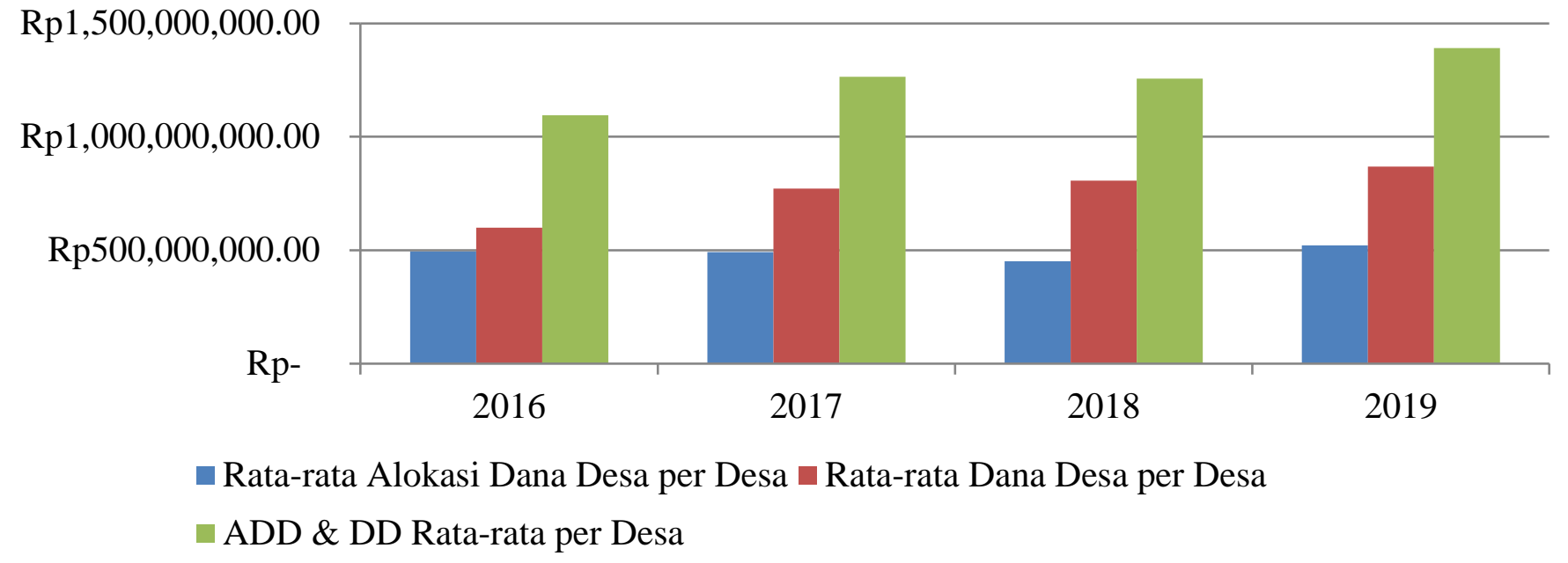

Sumber: data olahan

Rata-rata jumlah Dana Desa dan Alokasi Dana Desa di setiap Desa di Kecamatan Batang Cenaku semakin meningkat setiap tahunnya, dimana Dana Desa maupun Alokasi Dana Desa pada Tahun 2019 merupakan penerimann dengan jumlah yang paling tinggi. sedangkan proporsi implementasi Dana Desa dan Alokasi Dana Desa yang sudah disalurkan di setiap desa di Kecamatan Batang Cenaku Selama Tahun 2016 sampai dengan 2019 sebagai berikut.

Gambar 2

Proporsi Implementasin Dana Desa dan Alokasi Dana Desa di Kecamatan Batang Cenaku

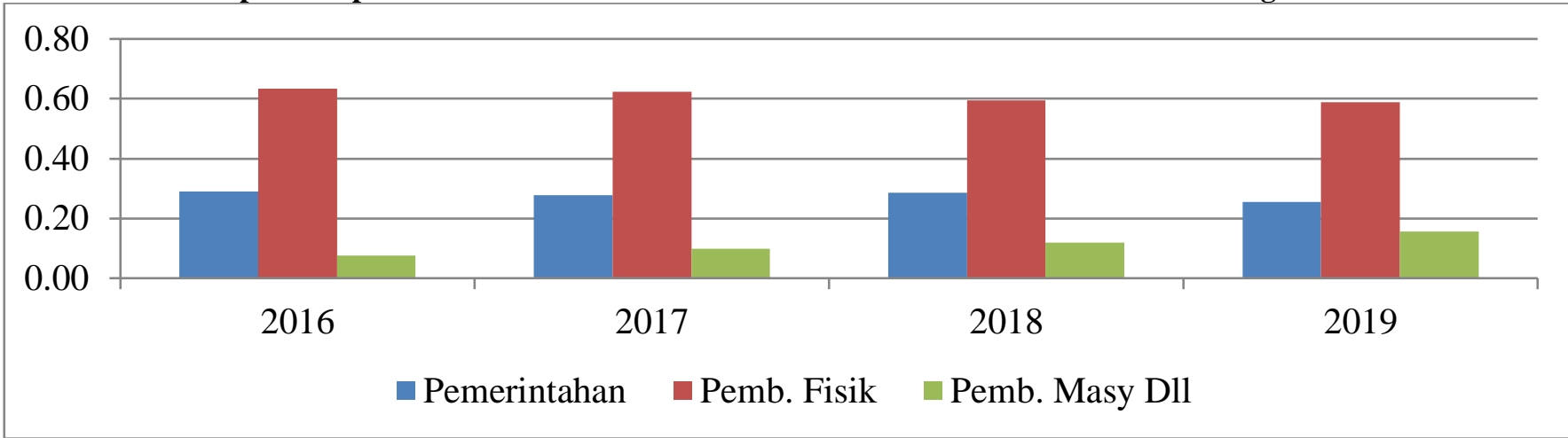

Sumber: data olahan

Gambar 2 diatas memperlihatkan bahwa dana desa dan alokasi dana desa yang di implementasikan oleh desa yang ada di Kecamatan Batang Cenaku selama 4 tahun berjalan secara garis besar peruntukannya masih didominasi untuk kegiatan penyelengaraan pemerintahan dan pembangunan fisik dengan proporsi yang begitu besar, meskipun proporsi untuk pemerintahan dan pembangunan fisik cenderung menurun, namun bila dibanding dengan implementasi untuk kegiatan-kegiatan pemberdayaan dan pembinaan masyarakat dan kegiatan lainnya relatif selalu jauh lebih besar. Unsur utama dari tata kelola pemerintahan yang baik adalah akuntabilitas, transparansi keterbukaan, dan aturan hukum (Sedarmayanti, 2004) Pelayanan publik diartikan sebagai pemberian layanan (Melayani) keperluan orang atau masyarakat yang mempunyai kepentingan pada organisasi itu sesuai dengan aturan pokok dan tata cara yang telah ditetapkan, tugas pelayanan lebih menekan kepada mendahulukan kepentingan umum, mempermudah urusan publik, sedangkan tugas mengatur lebih menekankan kepada kekuatan atau power yang melekat pada posisi jabatan birokrasi (Thoha 1995). Menurut Zeitmal dalam Hardiansyah (2013), kualitas layanan dapat dinilai dari lima dimensi yaitu Tangible, Reliability, Responsiviness, Assurance, dan Emphaty. Dalam pandangan sistem, kesejahteraan dapat diposisikan sebagai output/hasil dari sebuah proses pengelolaan input (sumberdaya) yang tersedia, dimana kesejahteraan sebagai output pada suatu titik dapat menjadi sumberdaya atau input untuk diproses menghasilkan tingkat kesejahteraan keluarga pada tahap berikutnya (Sunarti, 2006). Badan Pusat Statistik (2007), menjelaskan kesejahteraan adalah suatu kondisi dimana seluruh kebutuhan jasmani dan rohani dari rumah tangga dapat dipenuhi sesuai dengan tingkat hidup. 
Suwaji dan Suharmiyati, Analisis Dampak Implementasi Dana Desa dan Alokasi Dana Desa Terhadap Tata Kelola Pemerintahan, Kualitas Layanan Publik, Dan Kesejahteraan Masyarakat Desa (Studi Pada Desa di Kecamatan Batang Cenaku, Kabupaten Indragiri Hulu, Provinsi Riau)

kesejahteraan rakyat dapat diamati dari berbagai aspek yang spesifik yaitu: 1) Kependudukan; 2) Kesehatan dan Gizi; 3) Pendidikan; 4) Ketenagakerjaan; 5) Konsumsi dan Pengeluaran Rumah Tangga; 6) Perumahan dan Lingkungan; 7) Sosial budaya.

Semenjak digulirkanya dana desa dan alokasi dana desa, wacana good governance semakin menguat yang bertujuan untuk mengawasi dan menjamin agar dana desa yang nilainya cukup besar dapat dikelola dengan baik dan mampu mendatangkan nilai tambah (added value) dalam pembangunan desa secara khususnya dan Negara Indonesia secara umumnya (Hafeiz, 2018). Berdasarkan evaluasi yang dilakukan oleh Ombudsman dalam Ombudsman Brief (2017) hasilnya menyatakan bahwa meskipun dana desa sudah digulirkan sejak tahun 2015, namun kondisi pelayanan publik di desa masih banyak bermasalah. Mal administrasi dalam pelayanan publik masih menjadi masalah besar. Penelitian Yanhar Jamaluddin dkk (2018) implementasin dan penggunaan Dana Desa tidak memberi dampak signifikan bagi pertumbuhan pembangunan daerah dan nyatanya program pembangunan Desa tidak sinkron dengan kebijakan pembangunan Daerah (RPJM Daerah). Penelitian yang dialkukan oleh Rizky Winda N. (2017) kebijakan pemerintah desa dalam implementasin Dana Desa pasca UndangUndang Nomor. 6 tahun 2014 tentang desa untuk menciptakan Good Government di Desa hasil Implementasinnya mampu meningkatkan tata pemerintahan yang lebih baik. Hasil penelitian F.V Tangkumahat dkk (2017) menjelaskan bahwa Pembangunan dan Kemandirian di Kecamatan Pineleng meningkat setelah adanya program Dana Desa, hal ini disebabkan dengan adanya peningkatan infrastruktur berupa pembangunan jalan-jalan pertanian maka akses untuk pengangkutan dari lokasi perkebunan lebih mudah sehingga mempercepat proses penjualan hasil-hasil pertanian. Penelitian yang dilakukan oleh Mutia dan Liliana (2017) menjelaskan aspek implementasin dana desa secara umum telah sesuai dengan apa yang diatur dalam Permendagri No. 113/2014 dan mematuhi prinsip dasar implementasin dana, namun pelaporan dan masih menjadi masalah bagi beberapa desa, dimana belum semua desa yang diteliti memiliki sumber daya manusia yang menguasai aspek pelaporan dan pertanggungjawaban dan berkenaan dengan komposisi belanja desa, semua desa tidak memenuhi aturan yang berlaku hal ini mengakibatkan ketimpangan dalam pelaksanaan pembangunan di pedesaan.

Hasil yang diharapkan dari implementasi dana desa dan alokasi dana desa diantaranya adalah terciptanya tata kelola pemerintahan desa yang baik (good governance), peningkatan kualitas layanan publik dan kesejahteraan masyarakat desa, dengan kondisi seperti saat ini efektifitas dampak dari implementasi Dana Desa dan Alokasi Dana Desa bagi peningkatan tata kelola pemerintahan, peningkatan kualitas layanan publik, dan peningkatan kesejahteraan bagi masyarakat perlu diperhatikan dan dilakukan penilaian tingkat keberhasilannya.

\section{Metode}

Penelitian ini dilakukan di desa pada lingkup Kecamatan Batang Cenaku, Kabupaten Indragiri Hulu, Provinsi Riau. Populasi penelitian ini adalah masyarakat desa, responden penelitian berjumlah 98 orang yang berasal dari 6 (enam desa) sampel yang dianggap mampu memenuhi kebutuhan informasi penelitian. Untuk memperoleh gambaran terhadap objek yang diteliti melalui data sampel atau responden penelitian digunakan analisis deskriptif, Menurut Ghozali (2011) analisis deskriptif pada penelitian bertujuan untuk mendeskripsikan atau mengggambarkan fenomena ataupun karakteristik dari data. Karakteristik yang diamati diantara lain adalah frekuensi dan persentase data penelitian.

Deskriptif setiap variabel diuraikan berdasarkan jawaban dari butir-butir pernyataan, jawaban dari setiap butir pernyataan diberikan skor 1 sampai dengan 5 dengan ketentuan

Skor maksimal $=$ Klasifikasi tertinggi $\mathrm{x}$ Butir Pertanyaan $\mathrm{x}$ Jumlah Responden

Skor minimal $=$ Klasifikasi terendah $\mathrm{x}$ Butir Pertanyaan $\mathrm{x}$ Jumlah Responden

Range $=$ Skor Tertinggi - Skor Terendah

Sedangkan untuk penentuan Range Skor/interval kelas (Suyanto. S 2005) ditentukan sebagai berikut :

Range Skor $=\frac{\text { Skor tertinggi }- \text { Skor terendah }}{\text { Jumlah Klasifikasi }}$

Hasil yang diperoleh dikonsultasikan dengan tabel kriteria skor, dalam penyajiannya hasil analisis ini didasarkan pada distribusi frekuensi yang memberikan gambaran mengenai distribusi subyek menurut kategori-kategori nilai untuk setiap alternatif jawaban yang tersedia dalam kuesioner meliputi: Sangat Baik (SB), Baik (B), Cukup Baik (CB), Tidak Baik (TB), dan Sangat Tidak Baik (STB).

Untuk menguji hipotesis menggunakan analisis kuantitatif, menurut Sugiyono (2014) metode kuantitatif adalah metode yang berlandasan pada filsafat positifisme, digunakan untuk meneliti pada populasi dan sampel tertentu, pengumpulan data menggunakan instrumen penelitian, analisis data bersifat kuantitatif/statistik dengan tujuan untuk menguji hipotesis yang telah ditetapkan. Analisis regresi linear sederhana merupakan salah satu metode regresi yang dapat dipakai sebagai alat inferensi statistik untuk menentukan pengaruh sebuah variabel bebas (independent) terhadap variabel terikat (dependent). Persamaan Regresi : $\mathrm{Y}_{1}=\mathrm{a}+\mathrm{bX}+\mathrm{e} ; \mathrm{Y}_{2}=\mathrm{a}+\mathrm{bX}+\mathrm{e} ; \mathrm{Y}_{3}=\mathrm{a}+\mathrm{bX}+\mathrm{e}$ 
Suwaji dan Suharmiyati, Analisis Dampak Implementasi Dana Desa dan Alokasi Dana Desa Terhadap Tata Kelola Pemerintahan, Kualitas Layanan Publik, Dan Kesejahteraan Masyarakat Desa (Studi Pada Desa di Kecamatan Batang Cenaku, Kabupaten Indragiri Hulu, Provinsi Riau)

\section{Hasil}

Implementasin dana desa dan alokasi dana desa di diukur dengan menggunakan 8 indikator meliputi: 1) Pendanaan penyelenggaraan Pemerintahan Desa; 2) Perencanaan \& Pelaksanaan pembangunan Desa; 3) Pembinaan Aparatur Desa; 4) Pemberdayaan Masyarakat Desa; 5) Penghasilan tetap dan tunjangan kepala Desa dan perangkat Desa; 6) Operasional Pemerintah Desa; 7) Tunjangan Operasional Badan Permusyawaratan Desa; dan 8) Insentif rukun tetangga dan rukun warga. Dari semua butir pertanyaan hasilnya menunjukkan rata-rata skor sebesar 2,65, berdasarkan hasil tersebut bisa di ketahui bahwa Dana Desa dan alokasi dana desa selama ini sudah mampu di implementasikan dengan cukup baik. Tata Kelola pemerintahan desa di Kecamatan Batang Cenaku diukur berdasarkan indikator: 1) akuntabilitas; 2) transparansi; dan 3) kejelasan aturan/hukum. Dari semua butir pertanyaan hasilnya menunjukkan ratarata skor untuk tata kelola pemerintahan desa sebesar 3,64, berdasarkan hasil tersebut bisa di ketahui bahwa tata kelola pemrintahan desa termasuk berada pada kategori baik. Kualitas layanan publik desa di Kecamatan Batang Cenaku diukur berdasarkan jenis layanan publik dasar yang selayaknya tersedia di desa seperti; 1) Ketersediaan Administrasi Kependudukan; 2) Ketersediaan Data dan Informasi Pertanahan; 3) Ketersediaan Sarana dan Prasarana Pendidikan; 4) Ketersediaan Pelayanan Kesehatan Masyarakat; 5) Ketersediaan Layanan Aduan bagi masyarakat pengguna layanan. Dari semua butir pertanyaan hasilnya menunjukkan rata-rata skor sebesar 3,84, berdasarkan hasil tersebut bisa di ketahui bahwa Kualitas Layanan Publik di desa sampel masuk pada kategori baik. Kesejahteraan Masyarakat di ukur dengan menggunakan indikator: 1) Kependudukan; 2) Kesehatan dan Gizi; 3) Pendidikan; 4) Ketenagakerjaan; 5) Konsumsi dan Pengeluaran Rumah Tangga; 6) Perumahan dan Lingkungan; dan 7) Sosial budaya. Dari semua butir pertanyaan hasilnya menunjukkan rata-rata skor sebesar 3,93, berdasarkan hasil tersebut bisa di ketahui bahwa Kesejahteraan Masyarakat di desa sampel masuk pada kategori baik.

\section{Pengujian Hipotesis}

Analisis Redgresi

Hasil pengujian hipotesis untuk mengetahui pengaruh Implementasin dana desa dan alokasi dana desa terhadap tata kelola pemerintahan desa dan kualitas layanan publik dan kesejahteraan masyarakat desa dilakukan dengan menggunakan analisis regresi tiga tahap, hasilnya adalah sebagai berikut:

Tabel 1

Hasil Regresi Variabel Implementasin Dana Desa dan Alokasi Dana Desa (X) terhadap Tata Kelola Pemerintahan Desa (Y)

\begin{tabular}{|l|r|r|r|r|r|}
\hline \multirow{2}{*}{ Model } & \multicolumn{2}{|c|}{ Unstandardized Coefficients } & Standardized Coefficients & \multirow{2}{*}{ Sig } \\
\cline { 2 - 5 } & B & Std. Error & Beta & .407 & 5.459 \\
\hline (Constant) & 1.847 & .365 & &, 000 \\
Tata K. P.Des & .627 & .097 & 5.317 &, 000 \\
\hline
\end{tabular}

Sumber : Data Olahan

Persamaan regresinya adalah $\mathrm{Y}_{1}=1,847+0,627 \mathrm{X}$. Konstanta 1,847, artinya apabila nilai variabel bebas atau $\mathrm{X}$ $\left(\right.$ Implementasin Dana Desa dan Alokasi Dana Desa) $=0$, maka nilai variabel terikat atau $Y_{1}$ (Tata Kelola Pemerintahan Desa) sebesar 1,847, jika Implementasin Dana Desa dan Alokasi Dana Desa meningkat 1 satuan, maka Tata Kelola Pemerintahan Desa akan meningkat sebesar 0,627. Koefisien X bernilai positif berarti ada hubungan yang positif antara Implementasin Dana Desa dan Alokasi Dana Desa dengan Tata Kelola Pemerintahan Desa

Tabel 2

Hasil Regresi Implementasin Dana Desa dan Alokasi Dana Desa (X) terhadap Kualitas Layanan Publik di Desa (Y 2 ).

\begin{tabular}{|c|c|c|c|c|c|}
\hline \multirow{2}{*}{ Model } & \multicolumn{2}{|c|}{ Unstandardized Coefficients } & \multirow{2}{*}{$\frac{\text { Standardized Coefficients }}{\text { Beta }}$} & \multirow{2}{*}{$\mathrm{t}$} & \multirow{2}{*}{ Sig. } \\
\hline & $\mathrm{B}$ & Std. Error & & & \\
\hline (Constant) & 1.053 & .348 & .161 & 5.556 & .000 \\
\hline Kualitas La. Publik & .595 & .092 & & 4.791 & .000 \\
\hline
\end{tabular}

Sumber : Data Olahan

Persamaam regresinya adalah $\mathrm{Y}_{2}=1,053+0,595 \mathrm{X}$. Konstanta adalah 1,053, artinya apabila nilai variabel bebas atau X (Implementasin Dana Desa dan Alokasi Dana Desa) $=0$, maka nilai variabel terikat atau $\mathrm{Y}_{2}$ (Kualitas Layanan Publik) sebesar 1.053, jika Implementasin Dana Desa dan Alokasi Dana Desa mengalami peningkatan 1 satuan, maka Kualitas Layanan Publik akan meningkat sebesar 0,595. Koefisien X bernilai positif berarti ada hubungan yang positif antara Implementasin Dana Desa dan Alokasi Dana Desa dengan Kualitas Layanan Publik. 
Suwaji dan Suharmiyati, Analisis Dampak Implementasi Dana Desa dan Alokasi Dana Desa Terhadap Tata Kelola Pemerintahan, Kualitas Layanan Publik, Dan Kesejahteraan Masyarakat Desa (Studi Pada Desa di Kecamatan Batang Cenaku, Kabupaten Indragiri Hulu, Provinsi Riau)

Tabel 3

Hasil Regresi Implementasin Dana Desa dan Alokasi Dana Desa (X) terhadap Kesejahteraan Masyarakat Desa (Y).

\begin{tabular}{|l|r|r|r|r|r|}
\hline \multirow{2}{*}{ Model } & \multicolumn{2}{|c|}{ Unstandardized Coefficients } & \multicolumn{2}{|c|}{ Standardized Coefficients } & \multirow{2}{*}{ S Sig. } \\
\cline { 2 - 5 } & \multicolumn{1}{|c|}{ B } & Std. Error & Beta & .245 & 4.421 \\
\hline (Constant) & 1.023 & .365 & .000 \\
Kesejahteraan Mas. & .422 & .085 & 3.654 & .000 \\
\hline
\end{tabular}

Sumber : Data Olahan

Persamaan regresinya adalah $\mathrm{Y}_{3}=2,633+0,322 \mathrm{X}$. Konstanta adalah 2,633, artinya apabila nilai variabel bebas atau X (Implementasin Dana Desa dan Alokasi Dana Desa) $=0$, maka nilai variabel terikat atau $\mathrm{Y}_{3}(\mathrm{Kesejahteraan}$ Masyarakat Desa) sebesar 2.633. Nilai koefisien $\mathrm{X}$ bernilai positif berarti terjadi hubungan yang positif antara Implementasin Dana Desa dan Alokasi Dana Desa dengan Kesejahteraan Masyarakat Desa, jika Implementasin Dana Desa dan Alokasi Dana Desa mengalami peningkatan 1 satuan, maka Kesejahteraan Masyarakat Desa akan meningkat sebesar 0,422. Koefisien X bernilai positif berarti ada hubungan yang positif antara Implementasin Dana Desa dan Alokasi Dana Kesejahteraan Masyarakat Desa.

Koefisien Determinasi $\left(R^{2}\right)$

Tabel 4

Hasil Uji Koefisien Determinasi untuk variabel Implementasin Dana Desa dan Alokasi Dana Desa (X) Terhadap Tata kelola Pemerintahan Desa $\left(\mathbf{Y}_{1}\right)$

\begin{tabular}{|l|r|r|r|r|}
\hline Model & $R$ & R Square & Adjusted $R$ Square & Std. Error of the Estimate \\
\hline 1 & $.507^{\mathrm{a}}$ & .265 & & .217 \\
\hline
\end{tabular}

Sumber : Data Olahan

Hasil pengujian menunjukkan nilai R Squarea adalah 0,265. Jadi, sumbangan pengaruh variabel Implementasin Dana Desa dan Alokasi Dana Desa terhadap Variabel Tata Kelola Pemerintahan Desa sebesar 26,5\%.

Tabel 5

Hasil Uji Koefisien Determinasi untuk variabel Implementasin Dana Desa dan Alokasi Dana Desa (X) Terhadap Kualitas Layanan Publik $\left(\mathbf{Y}_{2}\right)$

\begin{tabular}{|l|r|r|r|r|}
\hline Model & $R$ & R Square & Adjusted $R$ Square & Std. Error of the Estimate \\
\hline 1 & $.427^{\mathrm{a}}$ & .176 & .168 & .45427 \\
\hline
\end{tabular}

Sumber : Data Olahan

Hasil pengujian menunjukkan nilai R Square adalah 0,176. Jadi, sumbangan pengaruh dari variabel Implementasin Dana Desa dan Alokasi Dana Desa terhadap Variabel Kualitas Layanan Publik yaitu 17,6\%.

Tabel 6

Hasil Uji Koefisien Keterminasi untuk variabel Implementasin Dana Desa dan Alokasi Dana Desa (X) Terhadap Kesejahteraan Masyarakat ( $\left.\mathbf{Y}_{3}\right)$

\begin{tabular}{|r|r|r|r|r|}
\hline Model & $R$ & R Square & Adjusted $R$ Square & Std. Error of the Estimate \\
\hline 1 & $.407^{\mathrm{a}}$ & .126 & .145 &, 45237 \\
\hline
\end{tabular}

Sumber : Data Olahan

Hasil pengujian menunjukkan nilai $\mathrm{R}$ Square adalah 0,126. Jadi, sumbangan pengaruh dari variabel Implementasin Dana Desa dan Alokasi Dana Desa terhadap Variabel Kesejahteraan Masyarakat Desa yaitu 12,6\%.

\section{Dampak Implementasin Dana Desa dan Alokasi Dana Desa terhadap Tata kelola Pemerintahan Desa}

Berdasarkan kriteria pengujian data, Implementasin Dana Desa dan Alokasi Dana Desa berdampak positif terhadap Tata kelola Pemerintahan. Keberadaan aturan yang jelas dan mengikat secara hukum mengenai tata-cara pengelolaan Dana Desa dan Alokasi Dana Desa memaksa penyelenggara pemerintahan desa sekaligus sebagai pengelola keuangan Desa disetiap desa harus berhati-hati dan serius dalam memanfaatkan anggran yang ada, hal inilah yang rupanya menjadi pedorong peningkatan Tata Kelola Desa dengan memanfaatkan anggaran yang tersedia. Hasil ini sejalan dengan penelitian Rizky Winda Nurrahma. (2018) dimana kebijakan pemerintah desa dalam implementasin Dana Desa pasca UndangUndang Nomor. 6 tahun 2014 tentang desa untuk menciptakan Good Government di Desa telah dilakukan dengan beberapa tahapan yakni tahap Perencanaan, Pelaksanaan, dan Pengawasan, hasil 
Implementasinnya mampu meningkatkan tata pemerintahan yang lebih baik. Hasil ini penelitian ini berbeda dari Hasil penelitian Umi Pratiwi dan Ulfah (2018) yang menjelaskan, akuntabilitas Dana Desa tidak berpengaruh terhadap signifikan terhadap tatakelola dan kinerja aparatur pemerintah desa. Pemerintah Daerah senantiasa harus melakukan sosialisasi peraturan pemerintah yang bekaitan dengan akuntabilitas Dana Desa sehingga semakin meningkat pemahamannya. Penelitian Meutia, dkk (2017) hasil penelitianya menjelaskan aspek implementasin dana desa secara umum telah sesuai dengan apa yang diatur dalam Permendagri No. 113/2014 dan mematuhi prinsip dasar implementasin dana, namun belum semua desa yang diteliti memiliki sumber daya manusia yang menguasai aspek pelaporan dan pertanggungjawaban dan berkenaan dengan komposisi belanja desa, semua desa belum memenuhi aturan yang berlaku hal ini mengakibatkan ketimpangan dalam pelaksanaan pembangunan di pedesaan.

\section{Dampak Implementasin Dana Desa dan Alokasi Dana Desa Terhadap Kualitas Layanan Publik.}

Berdasarkan kriteria pengujian data dapat diketahui bahwa Implementasin Dana Desa dan Alokasi Dana Desa berdampak positif terhadap Kualitas Layanan Publik di Desa. Dari hasil analisis deskriptif dan didukung pengamatan secara langsung, Pemerintah Desa di Kecamatan Batang cenaku rata-rata telah mampu meningkatkan ketersediaan sarana layanan meliputi ketersediaan sarana layanan administrasi kependudukan, data dan informasi pertanahan, ketersediaan sarana dan prasarana pendidikan, dan ketersediaan sarana kesehatan masyarakat. Hasil penelitian ini sejalan dengan penelitian Apriyansyah, dkk (2018) tentang efektifitas pelayana public di desa yang hasilnya menjelaskan bahwa pelayanan publik di desa sudah dapat berjalan dengan efektif cepat dan tepat, namun hasil penelitian ini tidak sejalan dengan catatan dan evaluasi dari Ombudsman Brief (2017) yang menyatakan bahwa meskipun dana desa sudah digulirkan sejak tahun 2015, namun kondisi pelayanan publik di desa masih banyak bermasalah.mal administrasi dalam pelayanan publik masih menjadi masalah besar, hal ini disebebkan karena minimnya koordinasi antar kementrian dan lembaga dalam penyediaan pelayanan public di desa serta absennya aturan turunan terkait standar pelayanan dasar ataupun pedoman pelaksanaan yang seharusnya sudah tersedia di desa sejak dana desa digulirkan. Penelitian Erdipa, dkk (2019) hasilnya menjelaskan bahwa kualitas pelayanan adi desa masih ada beberapa indikator yang belum berjalan sesuai dengan harapan masyarakat, antara lain ketidaknyamanan tempat pelayanan, termasuk sarana dan perasarana yang belum lengkap, pegawai belum efektif menggunakan SOP (Standart Operasional Prosedure) dalam proses pelayanan, dan masih ada pegawai yang tidak ramah dalam proses pelayanan.

\section{Dampak Implementasin Dana Desa dan Alokasi Dana Desa Terhadap Kesejahteraan Masyarakat Desa}

Berdasarkan kriteria pengujian data dapat diketahui bahwa Implementasin Dana Desa dan Alokasi Dana Desa berdampak positif terhadap Kesejahteraan Masyarakat Desa. Peningkatan kesejahteraan masyarakat desa di Kecamatan Batang Cenaku yang paling dirasakan adalah perbaikan dibidang, sarana jalan desa, jembatan dan lingkungan disekitar yang pada ahirnya menambah gairah dan mobilitas masyarakat dalam bekerja sehingga pada ahirnya mampu meningkatkan perekonomian masyarakat. Hasil peneitian ini mendukung penelitian Tangkumahat, dkk (2017) yang menjelaskan bahwa Pembangunan dan Kemandirian di Kecamatan Pineleng setelah adanya program Dana Desa maningkat, hal ini disebabkan dengan adanya peningkatan infrastruktur berupa pembangunan jalan-jalan pertanian maka akses untuk dan dari lokasi perkebunan lebih mudah sehingga mempercepat proses penjualan hasil-hasil pertanian. Penelitian Mustanir dan Darmiah (2016) yang menunjukkan Implementasin Dana Desa telah berjalan dengan baik dan hasil dari Implementasin Dana Desa telah mampu meningkatkan partisipasi dalam pembangunan desa dan telah mampu meningkatkan pembangunan di Desa, namun hasil penelitian ini tidak sejalan dengan hasil penelitian Jamaluddin, dkk (2018) mengenai Analisis Dampak Implementasin dan Penggunaan Dana Desa terhadap Pembangunan Daerah, dimana hasilnya menjelaskan bahwa Implementasin dan penggunaan Dana Desa tidak memberi dampak signifikan bagi pertumbuhan pembangunan daerah dan nyatanya program pembangunan Desa tidak sinkron dengan kebijakan pembangunan Daerah.

\section{Simpulan}

Berdasarkan hasil analisis data yang telah dilakukan dalam penelitian ini, diketahui bahwa Dana Desa di Desa dan Alokasi Dana Desa yang sudah diterima oleh desa-desa di lingkup Kecamatan Batang Cenaku dalam implementasinya sudah berjalan cukup baik dan berdampak positif bagi peningkatan Tata Kelola Pemerintahan, Kuaitas Layanan di Desa, dan peningkatan Kesejahteraan Masyarakat Desa, namun perlu upaya lebih khusunya untuk meningkatkan tata kelola pemerintahan desa dan kesejahteraan masyarakat, misalnya melalui perbaikan dan inovasi layanan dengan mengadopsi kemajuan teknologi yang ada dan berkembang pada saat ini, dari segi kesekjahteraan masyarakat desa, setelah era pembangunan fisik, upaya yang paling mungkin adalah memalui memanfaatkan dana desa secara lebih terarah pada kegiatan-kegiatan yang berpotensi mampu meningkatkakan perekonomian secara jangka panjang melalui upaya peningkatan kualitas Sumber Daya Manusia Desa, seperti mengoptimalkan peran BUMDes, 
Suwaji dan Suharmiyati, Analisis Dampak Implementasi Dana Desa dan Alokasi Dana Desa Terhadap Tata Kelola Pemerintahan, Kualitas Layanan Publik, Dan Kesejahteraan Masyarakat Desa (Studi Pada Desa di Kecamatan Batang Cenaku, Kabupaten Indragiri Hulu, Provinsi Riau)

pembinaan generasi muda pada kegiatan-kegiatan ekonomi produktif, dan menumbuhkembangkan Koperasi sebagai lembaga ekonomi masyarakat yang mampu mengelola potensi ekonomi yang sudah ada.

\section{Daftar Pustaka}

Ahmad Mustanir dan Darmiah. 2016, Implementasin Kebijakan Dana Desa Dan Partisipasi Dalam Pembangunan Di Desa Teteaji Kecamatan Tellu Limpoe Kabupaten Sidenreng Rappang. Jurnal Politik Profetik Volume 04, No. 2.

Apriyansyah, Isnaini M., Eko Priyo P., 2018, Efektivitas Sistem Informasi Desa (SID) Dalam Pelayanan Publik di Desa Dlingo, Kecamatan Dlingo, Kabupaten Bantul”. Jurnal Analisis Kebijakan dan Pelayanan Publik, Vol 4 No 1, jurnal.unhas.ac.id/index-php/jakpp.

Badan Pusat Statistik, 2017, Indikator Kesejahteraan Masyarakat.

Erdipa Panjaitan, Rosmala Dewi, Nina Angelia. 2019, The Role of the Village Government in Improving the Quality of Administrative Services to the Communit". Jurnal Perspektif, 8(1): 32-38 http://ojs.uma.ac.id/index.php/perspektif.

Euis Sunarti. 2006. Indikator Keluarga Sejahtera, Sejarah Pengembangan, Evaluasi dan Keberlanjutannya. Institut Pertanian Bogor, ISBN 978-602-8665-05-6.

Feiby Vencentia Tangkumahat, Vicky V. J. Panelewen, Arie D. P. Mirah. 2017, Dampak Program Dana Desa Terhadap Peningkatan Pembangunan Dan Ekonomi Di Kecamatan Pineleng Kabupaten Minahasa. Jurnal Agri-Sosio Ekonomi Unsrat,ISSN 1907- 4298 ,Volume 13 Nomor 2A, 335 - 342.

Ghozali, Imam. 2009. Aplikasi Analisis Multivariate dengan Program SPSS. Semarang: Undip

Hafiez Sofyani, Rudy Suryanto,Sigit Arie Wibowo, Harjanti Widiastuti, 2018, Praktik Pengelolaan Dan Tata Kelola Pemerintahan Desa Dlingo Di Kabupaten Bantul: Pembelajaran Dari Desa Percontohan. Jati: Jurnal Akuntansi Terapan Indonesia. Vol 1 No 1 Hal 1-16

Hardiansyah. 2011. Kualitas Pelayanan Publik. Yogyakarta: Gava Media

Inten Meutia, Liliana. 2017, Implementasin Dana Dana Desa. Jurnal Akuntansi Multi Program Universitas Sriwijaya. http:// dx.doi.org/10.18202.

Ombudsman Brief. 2017. Investigasi Ombudsman Republik Indonesia mengenai Implementasi Dana Desa di 12 Desa pada 6 Provinsi di Indonesia.

Peraturan Menteri Dalam Negeri No. 37 tahun 2007 Tentang Pedoman Pengelolaan Keuangan Desa.

Rizky Winda Nurrahma. 2018, Kebijakan Pemerintah Desa Dalam Implementasin Dana Desa Pasca Undang-Undang Nomor.6 Tahun 2014 Tentang Desa Untuk Menciptakan Good Government (Studi Pada Kasus Desa Bogem Kecamatan Jepra Kabupaten Belora .https://eprints.uins.ac.id/32807.

Sedarmayanti. 2004. Good Governance (Kepemerintahan Yang Baik). Bagian Kedua. CV. Mandar Maju. Bandung.

Sugiyono. 2014. Metode Penelitian Kuantitatif Kualitatif dan R\&D. Bandung : Alfabeta.

Suyanto, S. 2005. Metode Penelitian Sosial Berbagai Alternatif Pendekatan. Prenada Media Group. Jakarta

Thoha, 1995, kepemimpinan dalam manajemen, Jakarta: Raja Grafindo Persada.

Umi Pratiwi, 2018, Permata Ulfah Faktor Yang Mempengaruhi Kinerja Aparatur Pemerintah Desa Dalam Akuntabilitas Dana Desa . Jurnal Riset Akuntansi \& Dana. ISSN:2541 061X (Online). ISSN:233. 150.http:// ejournal. upi.e $\mathrm{du} /$ index.php/JRAK.

Undang-undang Nomor 6 tahun 2014 Tentang Desa.

Yanhar Jamaluddin, Asep Sumaryana, Budiman Rusli \& Rd. Ahmad Buchari, 2018, Analisis Dampak Implementasin dan Penggunaan Dana Desa terhadap Pembangunan Daerah. Jurnal Ilmu Pemerintahan dan Sosial Politik UMA, 6 (1): 14-24. ISSN 2550-1305. 